\title{
Enzymatic activity of strains of Ascosphaera apis, an entomopathogenic fungus of the honey bee, Apis mellifera *
}

\author{
M Gilliam, BJ Lorenz \\ US Department of Agriculture, Agricultural Research Service, Carl Hayden Bee Research Center, \\ 2000 E. Allen Road, Tucson, AZ 85719, USA
}

(Received 11 May 1992; accepted 3 October 1992)

\begin{abstract}
Summary - Unmated +, unmated -, and mated strains of Ascosphaera apis, the honey bee chalkbrood pathogen, were examined for production of 19 enzymes using the API ZYM system. All strains produced alkaline phosphatase, butyrate esterase, leucine aminopeptidase, acid phosphatase, and $\beta$-glucosidase. Since valine aminopeptidase was produced by unmated but not by mated strains, it may be a useful enzyme for identification of mycelial strains of the fungus. $\beta$-Galactosidase and $\alpha$ mannosidase may be candidate marker enzymes for identification of both unmated and mated strains. Few other molds associated with honey bees produce these 3 enzymes. Use of enzymes as taxonomic aids could simplify tests of bees and hive products for $A$ apis, particularly unmated strains.
\end{abstract}

\section{Ascosphaera / enzyme / honey bee / chalkbrood}

Ascosphaera apis is a heterothallic fungus that causes chalkbrood in larvae of the honey bee, Apis mellifera. Diagnosis of the disease in a bee colony is generally made on the basis of white, black, or gray larval mummies at the hive entrance, on the flight board, on the bottom board, and/ or in unsealed and sealed brood cells.

Bees and hive products sometimes must be certified free of $A$ apis in order to be brought into areas where the pathogen has not been found. Laboratory identifica- tion of $A$ apis from apparently healthy larvae, guts of adult bees, pollen, honey, and brood food is relatively easy when + and mycelia have mated to form characteristic spore cysts. Since mycelia alone are often isolated and can only be positively identified as $A$ apis by performing mating tests (Christensen and Gilliam, 1983), easier and faster methods are needed.

Results of tests for enzymes produced and carbohydrates assimilated by $A$ apis strains are not in agreement (Gochnauer

\footnotetext{
* Mention of a proprietary product or company name does not imply endorsement by the US Department of Agriculture.
} 
and Margetts, 1979; Chmielewski and Glinski, 1980/1981; Kowalska, 1984; Alonso et al, 1990). Recently, isolates of $A$ apis from Spain were examined using the API ZYM system (Alonso et al, 1990), but it is not clear whether these were,+- , and/or mated strains.

Using the API ZYM system, we determined and compared enzymatic profiles of $A$ apis unmated +, unmated -, and sporulated mated strains having spore cysts. Such profiles may be useful not only in identification of mycelial strains of $A$ apis but also in detection of strain differences and determination of the role of extracellular enzymes in virulence of $A$ apis.

Fifteen strains of $A$ apis were tested. Two of these were,+ 7 were -, and 6 were mated strains with spore cysts. Two of these, Nebr-1(+) and Nebr-31(-), were originally collected from Nebraska in 1971 (Christensen and Gilliam, 1983). The other unmated strains were fresh isolates from chalkbrood mummies from Tucson. When necessary, + and - hyphae were separated, and mating types were assigned on the basis of fruiting in crosses with the $\mathrm{Ne}$ braska strains and/or with ATCC 13785, LS Olive's + $A$ apis strain; crosses to obtain mated strains for API ZYM tests were then made (Christensen and Gilliam, 1983).

Preliminary tests revealed that previous methods used to prepare fungal inocula for API ZYM tests of molds (Bridge and Hawksworth, 1984; Satyanarayana et al, 1985; Gilliam et al, 1989) were unsatisfactory for $A$ apis even when various combinations of these methods and appropriate media for the bee pathogen were used. Difficulties were often encountered in production of sufficient fungal inocula and in variability of the level of enzyme activity.

Therefore, based on extensive preliminary work, the following procedure was de- vised to give reproducible results. Unmated strains of $A$ apis were grown for 9 days on plates of Sabouraud dextrose agar with $0.2 \%$ yeast extract (SDA-YE) maintained at $25^{\circ} \mathrm{C}$. Two to 3 pieces of mycelium from each culture were placed in separate sterile tissue grinders with 1-2 $\mathrm{ml}$ of sterile water and homogenized until a uniform turbid mycelial suspension was obtained. The suspension was examined microscopically, transferred to a sterile test tube, and standardized to McFarland No 4 with sterile water. Mated strains were grown for 2 wk on SDA-YE plates at room temperature to obtain mature spore cysts. Cultures showing good sporulation were processed as described above and included mycelia, spore cysts, and spores. API ZYM test strips (Analytab Products, Plainview, NY) were then inoculated, incubated, and read according to the manufacturer's directions.

Results of final replicated tests of 15 strains of $A$ apis are shown in figure 1. Data are presented using the methods of Bridge and Hawksworth (1984) which allow easy detection of differences and similarities in profiles of enzymatic activity of $A$ apis strains. Since the blocks in figure 1 represent ranges of activity, there were no differences in results between replicates. This is also probably due to the fact that the inocula were produced in exactly the same way for each replicate. All strains were tested twice at minimum; some, particularly the reference strains (Nebr-1, Nebr-31, and ATCC 13785), were tested as many as 4 times. Thus, the methods developed are reproducible.

Uninoculated Sabouraud dextrose broth with $0.2 \%$ yeast extract gave negative results in API ZYM tests. Myristate lipase, cystine aminopeptidase, trypsin, $\alpha$-galactosidase, $\beta$-glucuronidase, $\alpha$-glucosidase, and $\alpha$-fucosidase were not produced by any strains. Only one strain produced chymotrypsin. All strains produced alkaline 


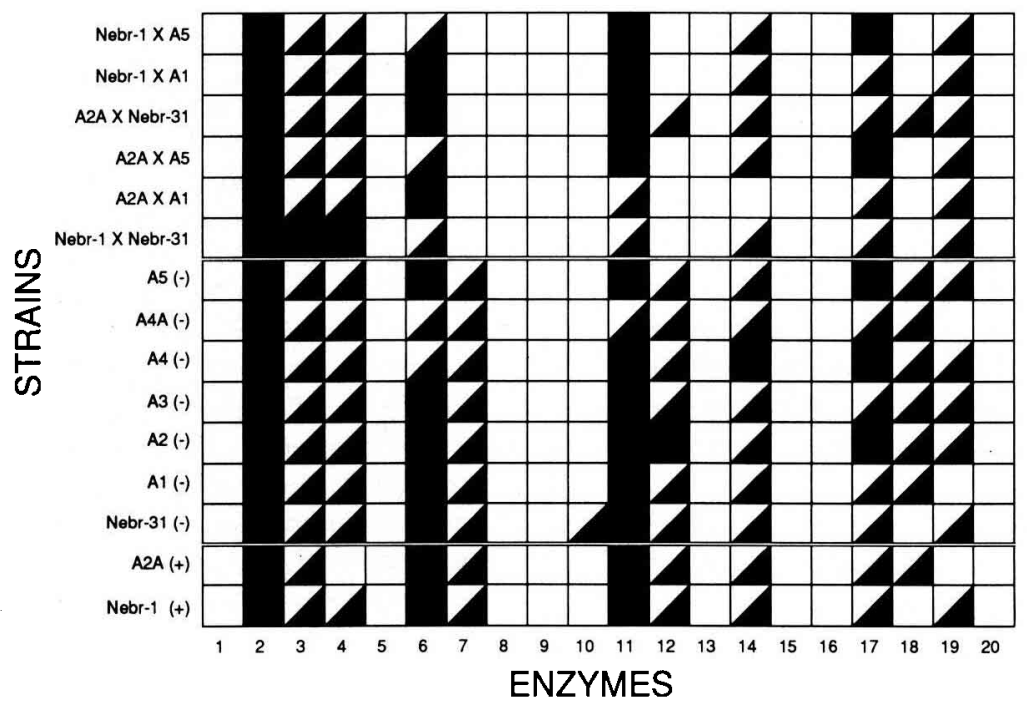

Fig 1. Results of the API ZYM enzyme test system with 15 strains of Ascosphaera apis. Strong positive reactions $(20$ to $\geq 40 \mathrm{~nm}$ ) are indicated by a solid block, and moderate reactions $(5$ to $20 \mathrm{~nm}$ ) by a half-solid block. 1 = Control; 2 = alkaline phosphatase; 3 = butyrate esterase; 4 = caprylate esteraselipase; 5 = myristate lipase $; 6$ = leucine aminopeptidase; $7=$ valine aminopeptidase; $8=$ cystine aminopeptidase; $9=$ trypsin; $10=$ chymotrypsin; $11=$ acid phosphatase; $12=$ phosphoamidase; $13=\alpha$ galactosidase; $14=\beta$-galactosidase; $15=\beta$-glucuronidase; $16=\alpha$-glucosidase; $17=\beta$-glucosidase; $18=N$-acetyl- $\beta$-glucosaminidase; $19=\alpha$-mannosidase; $20=\alpha$-fucosidase.

phosphatase, butyrate esterase, leucine aminopeptidase, acid phosphatase, and $\beta$-glucosidase. All but one strain produced caprylate esterase-lipase and $\beta$-galactosidase. Alkaline phosphatase was the only enzyme produced in high concentration ( $\geq 30 \mathrm{nmol}$ ) by all strains.

There are some differences in our results compared to those obtained from isolates from Spain (Alonso et al, 1990) which could be due to variations in strains, methods, or the API ZYM kits used. For example, only one of our unmated strains approached the levels of phosphoamidase that were found in Spanish strains, and $\alpha$ mannosidase was not produced by 3 of our strains. Also, our strains did not pro- duce $\alpha$-glucosidase, whereas $78.3 \%$ of Spanish strains produced detectable amounts of $10 \mathrm{~nm}$.

Predominantly mycelial inocula of some fungal species produce the same enzymes, although in reduced amounts, as spore suspensions (Bridge and Hawksworth, 1984; Gilliam et al, 1989). However, in the $A$ apis strains that we tested, valine aminopeptidase was produced by unmated but not by mated strains. Also, phosphoamidase and $N$-acetyl- $\beta$-glucosamidase were produced by all or most, respectively, of the unmated but only one of the mated strains. Thus, these 3 enzymes may be useful for identification of mycelia of $A$ apis associated with honey bees. Of these, va- 
line aminopeptidase may be the most useful marker since few molds associated with honey bees produce this enzyme (Gilliam et al, 1989). $\beta$-Galactosidase and $\alpha$ mannosidase may be candidate marker enzymes for identification of both mated and unmated $A$ apis strains since they were produced by most strains tested but are rarely produced by bee-associated molds (Gilliam et al, 1989). Overall, + and - strains gave similar results, but more unmated strains, particularly + ones, must be evaluated.

In this study, cultures were incubated for the minimum time required for all strains within a group (unmated or mated) to produce sufficient inocula for the API ZYM test strips and for mature spore cysts to be present in mated strains. This required $9 \mathrm{~d}$ of incubation for unmated strains and 2 wk for mated strains. We recognize that enzyme profiles may be affected both by growth times and the type of inoculum. However, this does not negate the possible use of enzymes as markers for $A$ apis from bees and hive products. Plating would be required to isolate molds for testing, and the same incubation times that we used should produce sufficient inocula and reproducible results.

We shall use these methods to test additional $A$ apis strains, particularly those from other geographical areas and from other bee species as they become available, to determine whether the enzymatic profiles obtained in the present study are indicative of most $A$ apis strains and to test further the feasibility of using marker enzymes to identify unmated $A$ apis strains and to distinguish $A$ apis from other molds commonly associated with bees.

\footnotetext{
Résumé - Activité enzymatique de souches d'Ascosphaera apis, champignon entomopathogène de l'abeille
}

(Apis mellifera L). Le champignon Ascosphaera apis, responsable du couvain plâtré chez l'abeille, existe à l'état de mycélium (+ ou -) et de formes fécondées sporulées. À l'aide du système API ZYM, nous avons déterminé et comparé les profils enzymatiques de 15 souches (soit non fécondées + , non fécondées -, soit fécondées et sporulées avec des sporocystes). Ces profils peuvent être utiles pour identifier des souches mycéliennes, pour détecter des différences de souches et pour déterminer le rôle des enzymes extracellulaires dans la virulence d' $A$ apis. Des méthodes de préparation d'inoculums pour les tests ont été mises au point, car les méthodes existantes pour les moisissures ne donnaient pas satisfaction. Toutes les souches ont produit de la phosphatase alcaline, de la butyrate estérase, de la leucine aminopeptidase, de la phosphatase acide et de la $\beta$-glucosidase. La valine aminopeptidase a été produite par les souches non fécondées mais non par les souches fécondées. La phosphoamidase et la $\mathrm{N}$-acétyl- $\beta$-glucosaminidase ont été respectivement produites par toutes ou presque toutes les souches non fécondées, mais par une seule des souches fécondées. Ces 3 enzymes peuvent donc être utilisés pour identifier les souches mycéliennes d'A apis associées aux abeilles. Parmi eux, la valine aminopeptidase est peut-être le marqueur le plus utile, puisque peu de moisissures associées aux abeilles la produisent. Pour la même raison, la $\beta$-galactosidase et l' $\alpha$ mannosidase, produites par la plupart des souches testées, sont des candidats comme enzymes marqueurs pour les souches fécondées et non fécondées d' $A$ apis.

Ascosphaera apis / enzyme / couvain plâtré

Zusammenfassung - Enzymatische Aktivität von Stämmen von Ascosphae- 
ra apis, ein insektenpathogener Pilz der Honigbiene, Apis mellifera L. Der Kalkbruterreger des Honigbiene, Ascosphaera apis, kommt in Myzelform (+ oder -) vor, und auch als sporulierende Form nach der Paarung. Unter Benutzung des API ZYMSystems bestimmten und verglichen wir die enzymatischen Profile von 15 Stämmen (entweder ungepaart + , ungepaart oder sporulierte gepaarte Stämme mit Sporenzysten). Solche Profile können für die Bestimmung von myzelialen Stämmen, die Entdeckung von Unterschieden zwischen Stämmen und die Bestimmung der Rolle von extrazellulären Enzymen bei der Virulenz von $A$ apis nützlich sein. Es wurden Methoden zur Vorbereitung des Impfmaterials entwickelt, da sich die bisherigen Verfahren für den Schimmel als wenig zufriedenstellend erwiesen haben.

Alle Stämme erzeugten alkaline Phosphatase, Butyrat-Esterase, LeucinAminopeptidase, saure Phosphatase und $\beta$-Glucosidase. Valin-Aminopeptidase wurde von ungepaarten, aber nicht von gepaarten Formen erzeugt. Auch PhosphoAmidase and $\mathrm{N}$-acetyl- $\beta$-Glucosaminidase wurden von allen oder von den meisten der ungepaarten Formen, aber nur von einem der gepaarten Stämme erzeugt. Deshalb können diese drei Enzyme für die Bestimmung der Myzelformen von $A$ apis in ihrem Vorkommen bei der Honigbiene von Nutzen sein. Von diesen könnte die Valin-Aminopeptidase der beste Marker sein, da nur wenige Schimmelpilze der Honigbiene dieses Enzym erzeugen. Aus demselben Grunde könnten möglicherweise $\beta$-Galactosidase and $\alpha$-Mannosidase, die von den meisten geprüften Stämmen erzeugt werden, als Marker-Enzyme sowohl für ungepaarte wie für gepaarte Stämme von $A$ apis dienen.

\section{Ascosphaera / Enzyme / Kalkbrut / Ho- nigbiene}

\section{REFERENCES}

Alonso JM, Rey JM, Hermoso de Mendoza J, Cardenal JA, Antón JM, Naranjo G, Gil MC, Hermoso de Mendoza M (1990) Caracterización enzimática de Ascosphaera apis aislada en España a partir de larvas de abeja melífera (Apis mellifera $L$ ) afectadas por la Ascosferiosis (Pollo Escayolado). in: 5th Congr Nac Apícola Don Benito, Spain, 44-46

Bridge PD, Hawksworth DL (1984) The API ZYM enzyme testing system as an aid to the rapid identification of Penicillium isolates. Microbiol Sci 1, 232-234

Chmielewski M, Glinski Z (1980/1981) Badania nad patogennościa Ascosphaera apis dla czerwia pszczoly miodnej Apis mellifera L. Czesć I. Wlaściwości biochemiczne $A$ apis. Ann Univ M Curie-Sklodowksa 35/36, 71-82

Christensen M, Gilliam M (1983) Notes on the Ascosphaera species inciting chalkbrood in honey bees. Apidologie 14, 291-297

Gilliam M, Prest DB, Lorenz BJ (1989) Microbiology of pollen and bee bread: taxonomy and enzymology of molds. Apidologie 20, 53-68

Gochnauer TA, Margetts VJ (1979) Properties of honeybee larvae killed by chalkbrood disease. J Apic Res 18, 212-216

Kowalska M (1984) Wlaściwosći biochemiczne Ascosphaera apis i Bettsia alvei. Pol Arch Wet 24, 7-15

Satyanarayana T, Chavant L, Montant C (1985) Applicability of API ZYM for screening enzyme activity of thermophilic moulds. Trans BrMycol Soc 85, 727-730 